\title{
DIETARY GENDER DIFFERENCES IN TERMS OF THE RISK OF ATHEROGENESIS IN POLAND*
}

\author{
Angelika Śmidowicz ${ }^{\bowtie}$, Julita Reguła \\ Department of Human Nutrition and Hygiene, Poznań University of Life Sciences \\ Wojska Polskiego 31, 60-624 Poznań, Poland
}

\begin{abstract}
Introduction. Diet plays an important role in prevention of atherosclerosis. The objective of the study was to assess differences in the dietary intake and nutritional status in women and men in terms of atherogenesis risk. Material and methods. The study involved 41 women and 49 men aged 40+. The nutrient intake was assessed using 7-day dietary records. The nutritional status was estimated on the basis of antropometric measurements and biochemical blood parameters. The differences between diets and the nutritional status depending on sex was evaluated by oneway analysis of variance. The dependencies between the nutritional status and the diet factors were assessed using multiple regression.

Results and discussion. It was found that a significant proportion of the women and men were overweight or obese, had lipid disorders and impaired fasting glucose. Diets of women and men were poorly balanced. A significant correlation between the level of energy from protein, as well as the energy supply and the LDL cholesterol concetration was found in the women. A positive correlation between energy from protein as well as total energy in the diet and body weight, was observed in women and men. Moreover, protein intake was positively correlated with BMI and waist circumference among the men. In the men, the level of serum triglycerides correlated with an increase in dietary cholesterol and a decrease in energy value.

Conclusion. This study indicates that an inadequate diet among both men and women represents a real health danger of developing atherosclerotic plaque.
\end{abstract}

Key words: lipid disorders, nutritional status, nutrition, atherosclerosis

\section{INTRODUCTION}

Cardiovascular diseases (CVDs) are responsible for over 17.3 million deaths per year and are the leading causes of death in the world (Mendis et al., 2011). The atherosclerosis process plays an important role in the pathogenesis of the CVDs. Dyslipidemia, next to hypertension, is a major factor that promotes the process of atherosclerosis. Most authors suggested that adequate nutrition is one of the most important prevention methods against atherosclerosis and its complications. An appropriate diet can decrease lipid concentration. Low dietary intakes of saturated fatty acids (SFA), cholesterol and salt, and high intake of fruits, vegetables and fish prevent the atherogenesis process. The next risk factor, closely linked to diet and physical inactivity, is obesity. Maintaining the proportion between energy requirements and its expediture

\footnotetext{
*This study was partly financed by grants to young researchers and PhD students of the Food Sciences and Nutrition Department of the Poznań University of Life Sciences in 2014 no: 507.786.64.
}

凶angelika.smidowicz@up.poznan.pl 
prevents overweight and obesity. An appropriate diet, as a modifiable risk factor, is the base of lipid disorders treatment. Diet constitutes a necessary addition to pharmacotherapy and increases the effectiveness of thereof and, in some cases, reduces the need for pharmacotherapy (Mendis et al., 2011; Report..., 2003).

\section{MATERIAL AND METHODS}

The study included 41 women aged $57.3 \pm 7.3$ years, and 49 men aged $57.4 \pm 7.7$ years. A test group were taken from Wielkopolska region and it was random, potentially healthy people. The protocol of the study was approved by the Research Ethics Committee of Poznan University of Medical Sciences and registered as no. 1016/13. All participants provided written informed consent. To evaluate diet used a 7-day dietary record. The energy value and nutrient content in daily food rations (DFRs) of patients were calculated using the Dietetyk computer programme by JuMaR. The data recorded from all 90 diets were compared to the recommended daily allowances respective for a given sex, age, body mass and physical activity and the average percentage of the reference daily intake was determined. On the basis of the guidelines of national and world experts from the Polish Forum for Prevention, Food and Nutrition Institute in Warsaw, National Cholesterol Education Program Adult Treatment Panel III (ATP III) and World Health Organization a model of health-promoting nutrition was established. It was assumed that proteins, carbohydrates and fats should constitute $12 \%, 58 \%$ and $30 \%$ of energy value of a diet; SFA, monounsaturated fatty acids (MUFA) and polyunsaturated fatty acids (PUFA) should provide $10 \%$, $12 \%$ and $8 \%$ of the daily energy requirement, respectively. The upper limit for cholesterol intake was set at $300 \mathrm{mg}$ (Jarosz, 2012; Kłosiewicz-Latoszek et al., 2008; National cholesterol..., 2002; Report..., 2003).

The nutritional status was estimated on the basis of anthropometric measurements and biochemical blood parameters (total cholesterol (TC), low- and high-density lipoprotein (LDL and HDL) cholesterol, triacylglycerols (TG), fasting blood glucose level). Laboratory analyses were performed at a certified analytical laboratory. Blood samples were collected after 7 days of conducting a nutritional diary from the subjects, who had fasted for minimum 12 hours before venepuncture. Serum TC, HDL-cholesterol and TG levels were determined using standard methods on an Abbott ARCHITECT ci4100 analyzer. LDL-cholesterol was calculated using the Friedewald's formula (Friedewald et al., 1972). Glucose levels were determined in the Abbott ARCHITECT ci4100 using the Hexokinase/G-6-PDH reagent kit. The obtained values of the lipid profile compared with the guidelines of the European Society of Cardiology from 2003 (De Backer et al., 2003). The fasting glucose levels compared with the guidelines of the American Diabetes Association (García-Alcalá et al., 2012).

The differences between the intake of energy and nutrients, anthropometric parameters, lipid profile and glucose level depending on the sex of the patients was evaluated by oneway analysis of variance (ANOVA). The dependencies between anthropometric and biochemical parameters and diet factors (energy value and nutritive value of DFRs) were assessed using multiple regression.

\section{RESULTS}

It was found that the average BMI value for the men fell within the range considered as overweight, while the mean BMI for the women was in the normal range (Jarosz et al., 2010; Table 1). However, an analysis of the distribution of the women and men in different BMI classes showed that $56 \%$ of the women and only $31 \%$ of the men had normal body weight, while

Table 1. Selected anthropometric parameters in patients $(\bar{x} \pm \mathrm{SD})$

\begin{tabular}{lcc}
\hline \multirow{1}{*}{\multicolumn{1}{c}{ Parameter }} & \multicolumn{2}{c}{ Examined group } \\
\cline { 2 - 3 } & women & men \\
\hline Body weight, kg & $62.92 \pm 6.78^{\mathrm{b}}$ & $82.12 \pm 15.21^{\mathrm{a}}$ \\
BMI, kg/m $\mathrm{m}^{2}$ & $24.70 \pm 2.80$ & $27.93 \pm 9.52$ \\
Waist circumference, $\mathrm{cm}$ & $80.15 \pm 7.41^{\mathrm{b}}$ & $96.62 \pm 11.42^{\mathrm{a}}$ \\
Hip circumference, $\mathrm{cm}$ & $99.16 \pm 5.72^{\mathrm{b}}$ & $102.34 \pm 6.65^{\mathrm{a}}$ \\
WHR & $0.81 \pm 0.05^{\mathrm{b}}$ & $0.94 \pm 0.07^{\mathrm{a}}$ \\
\hline
\end{tabular}

a, bStatistically significant difference between women and men in the examined group at $p<0.05$. 
$41 \%$ of the women and $45 \%$ of the men were found to be overweight. Obesity was recorded in $2 \%$ of the women, while nearly one quarter of the men were obese. The average waist circumference (WC) was significantly lower in the women than in the men and for both sexes it exceeded the boundary values (Jarosz et al., 2010). Disturbing data were obtained from the assessment of body type based on WHR (waist to hip ratio). Namely, the majority of women (61\%) and $27 \%$ of men were characterised by the abdominal obesity. The mean TC and LDL level in both the women and men exceeded the reference values (Table 2). Although the average values of the other parameters of the lipid profile did not exceed the reference values, as many as $22 \%$ of the women and $27 \%$ of the men had elevated TG levels. Moreover, a reduced concentration of the HDL fraction was recorded in $7 \%$ of the women and $8 \%$ of the men. The mean fasting glucose concentration was within the normal range, but in $35 \%$ of the men and $22 \%$ of the women the reference values were exceeded.

Table 2. Selected biochemical blood parameters in patients $(\bar{x} \pm \mathrm{SD})$

\begin{tabular}{lrc}
\hline \multirow{1}{*}{ Parameter } & \multicolumn{2}{c}{ Examined group } \\
\cline { 2 - 3 } & \multicolumn{1}{c}{ women } & men \\
\hline Total cholesterol, mg/dl & $213.17 \pm 56.42$ & $211.45 \pm 38.53$ \\
C-HDL, mg/dl & $64.61 \pm 12.37^{\mathrm{a}}$ & $55.14 \pm 15.35^{\mathrm{b}}$ \\
C-LDL, mg/dl & $135.65 \pm 38.39$ & $130.81 \pm 30.27$ \\
Triacylglycerols, mg/dl & $110.78 \pm 43.35$ & $134.65 \pm 90.70$ \\
C-LDL/C-HDL & $2.19 \pm 0.87$ & $2.49 \pm 0.71$ \\
TC/C-HDL & $3.40 \pm 1.16$ & $4.01 \pm 0.97$ \\
Fasting glucose, $\mathrm{mg} / \mathrm{dl}$ & $93.27 \pm 20.60$ & $97.65 \pm 17.91$ \\
\hline
\end{tabular}

a, bStatistically significant difference between women and men in the examined group at $p<0.05$.

Table 3 shows the mean value of the energy supply and intake of macronutrients provided with DFRs of the patients and the percentages of reference daily intakes. The amount of energy supplied from the diet was insufficient in $48 \%$ of the women and $56 \%$ of the men. Although the average intake of protein and fat in the men was within the normal range, $34 \%$ of them consumed an excess of those components. Among the women, $40 \%$ consumed excess protein and $29 \%$ provided excess fat in their diet. The average intake of carbohydrates was too low in the group of men, but it was observed that as many as $60 \%$ of the women consumed them in too small quantities. The share of energy from macronutrients was improperly balanced. There was an excessive proportion of energy from fat and protein. The amount of energy from carbohydrates was too low in $21 \%$ of the women and $32 \%$ of the men. The average intake of sucrose did not exceed the upper limit in any group, but as many as $29 \%$ of the women and $10 \%$ of the men exceeded it. The mean intake of dietary fiber was sufficient only in the men, but an insufficient fiber intake was observed in over $50 \%$ of the men and up to $74 \%$ of the women. The intake of cholesterol exceeded the upper limit in $40 \%$ of men. Among the women, only $5 \%$ were over the limit. An excessive intake of SFA in $45 \%$ of the women and $46 \%$ of the men simultaneous with too little supply of PUFA was worrying. The optimal supply of PUFA was reported for only $7 \%$ of the women and $6 \%$ of the men. The share of energy from SFA exceeded the recommended level in the vast majority of the women $(65 \%)$ and men $(78 \%)$ while a PUFA deficiency in $88 \%$ of the women and $74 \%$ of the men. Table 4 presents the average daily intake of minerals and vitamins in the DFRs of the examined and the percentage of fulfilment of the standards for these components. DFRs of the patients were deficient in potassium and calcium, whereas the women consumed an insufficient amount of magnesium. In both groups an excessive supply of sodium, phosphorus and copper was shown, and in the diet of the men an excess of iron was observed. Both the men and women's mean supply of vitamins D, $\mathrm{C}$ and folate was not enough. Although the average intake of vitamin $\mathrm{A}$ and $\mathrm{E}$ was in the normal range, as many as $33 \%$ of the women and $40 \%$ of the men consumed an insufficient amount of vitamin A, 46\% of the women and $36 \%$ of the men consumed an insufficient amount of vitamin E. In both groups the average supply of riboflavin and vitamin $B_{12}$ exceeded the recommended allowance, just as that of vitamin $\mathrm{B}_{6}$ in the group of men. 
Śmidowicz, A., Reguła, J. (2015). Dietary gender differences in terms of the risk of atherogenesis in Poland. Acta Sci. Pol. Technol. Aliment., 14(3), 257-267. DOI: 10.17306/J.AFS.2015.3.27

Table 3. Energy and macronutrients in DFR of patients

\begin{tabular}{|c|c|c|c|c|}
\hline \multirow{3}{*}{ Nutrient } & \multicolumn{4}{|c|}{ Examined group } \\
\hline & \multicolumn{2}{|c|}{ women } & \multicolumn{2}{|c|}{ men } \\
\hline & $\bar{x} \pm \mathrm{SD}$ & $\begin{array}{c}\% \text { allowance } \\
\text { uptake }\end{array}$ & $x \pm \mathrm{SD}$ & $\begin{array}{c}\% \text { allowance } \\
\text { uptake }\end{array}$ \\
\hline Energy, kcal & $1762.44 \pm 322.2^{\mathrm{b}}$ & 86 & $2185.42 \pm 485.30^{\mathrm{a}}$ & 84 \\
\hline Energy, MJ & $7.38 \pm 1.35^{\mathrm{b}}$ & 86 & $9.15 \pm 2.03^{\mathrm{a}}$ & 84 \\
\hline Protein, $\mathrm{g}$ & $65.91 \pm 14.24^{b}$ & 127 & $82.46 \pm 18.63^{\mathrm{a}}$ & 106 \\
\hline Fat, $g$ & $70.18 \pm 16.16^{b}$ & 120 & $90.47 \pm 24.03^{\mathrm{a}}$ & 104 \\
\hline SFA, $g$ & $24.51 \pm 6.73^{\mathrm{b}}$ & 124 & $33.21 \pm 11.55^{\mathrm{a}}$ & 115 \\
\hline MUFA, g & $24.52 \pm 6.54^{\mathrm{b}}$ & 106 & $33.98 \pm 10.51^{\mathrm{a}}$ & 98 \\
\hline PUFA, g & $9.96 \pm 4.69^{b}$ & 64 & $13.46 \pm 5.48^{\mathrm{a}}$ & 58 \\
\hline Dietary cholesterol, mg & $244.70 \pm 76.77^{b}$ & 82 & $337.43 \pm 152.77^{\mathrm{a}}$ & 112 \\
\hline Carbohydrates, g & $229.56 \pm 46.98^{b}$ & 89 & $269.36 \pm 68.77^{\mathrm{a}}$ & 72 \\
\hline Sucrose, $\mathrm{g}$ & $49.86 \pm 23.79$ & 112 & $47.15 \pm 20.12$ & 73 \\
\hline Dietary fibre, $g$ & $17.76 \pm 5.09^{\mathrm{b}}$ & 74 & $20.79 \pm 5.96^{\mathrm{a}}$ & 86 \\
\hline Protein, \% E & $15.01 \pm 2.16$ & 125 & $15.21 \pm 1.99$ & 127 \\
\hline Fat, \% E & $35.81 \pm 4.58$ & 119 & $37.16 \pm 4.79$ & 124 \\
\hline SFA, \% E & $12.43 \pm 2.00$ & 124 & $13.49 \pm 2.89$ & 135 \\
\hline MUFA, \% E & $12.48 \pm 2.10^{\mathrm{b}}$ & 104 & $13.93 \pm 2.71^{\mathrm{a}}$ & 116 \\
\hline PUFA, \% E & $5.07 \pm 2.23$ & 63 & $5.60 \pm 1.97$ & 70 \\
\hline Carbohydrates, \% E & $52.12 \pm 4.92^{\mathrm{a}}$ & 90 & $49.44 \pm 6.31^{\mathrm{b}}$ & 85 \\
\hline
\end{tabular}

${ }^{\mathrm{a}, \mathrm{b}}$ Statistically significant difference between women and men in the examined group at $p<0.05$.

An analysis of the relationship between nutrition and the nutritional status showed that there was a statistically significant correlation $(R=0.48, p<0.006)$ between the LDL cholesterol level in the women and the energy supply in the diet and the percentage share of energy from protein. The high percentage of energy from protein correlated positively, while the total energy intake correlated inversely. A similar pattern was observed for the supply of energy and the total protein intake in the women $(R=0.50, p<0.005)$. In both groups a positive correlation between body weight and the level of dietary energy intake and energy from protein was also observed $(R=0.44$, $p<0.02$ for the women, $R=0.51, p<0.0009$ for the men). The best results of body weight were recorded for energy supply about $1200-1400 \mathrm{kcal}$ and protein at the level of $12-15 \%$ in men. Among women with energy supply at the level of 1200-1600 kcal and 10-14\% energy from protein (Fig. 1 and 2). In addition, among the men, the total energy intake and energy percentage from protein $(R=0.43, p<0.008)$ correlated positively with BMI. The value of WC correlated with an increase of energy supply from protein and a decrease in calorie value $(R=0.42$, $p<0.013)$. In the men, it was also demonstrated that the level of TG correlated with an increase in dietary cholesterol and a decrease in energy value $(R=0.55$, $p<0.0003)$. 
Table 4. Minerals and vitamins in DFR of patients

\begin{tabular}{|c|c|c|c|c|}
\hline \multirow{3}{*}{ Nutrient } & \multicolumn{4}{|c|}{ Examined group } \\
\hline & \multicolumn{2}{|c|}{ women } & \multicolumn{2}{|c|}{ men } \\
\hline & $\bar{x} \pm \mathrm{SD}$ & $\begin{array}{c}\% \text { allowance } \\
\text { uptake }\end{array}$ & $\bar{x} \pm \mathrm{SD}$ & $\begin{array}{c}\% \text { allowance } \\
\text { uptake }\end{array}$ \\
\hline Sodium, mg & $1739.59 \pm 442.50^{\mathrm{b}}$ & 124 & $2441.24 \pm 748.69^{\mathrm{a}}$ & 173 \\
\hline Potassium, mg & $2825.99 \pm 788.54^{\mathrm{b}}$ & 60 & $3208.46 \pm 763.34^{\mathrm{a}}$ & 68 \\
\hline Calcium, mg & $537.11 \pm 150.06^{\mathrm{b}}$ & 46 & $636.00 \pm 255.53^{\mathrm{a}}$ & 63 \\
\hline Phosphorus, mg & $1031.60 \pm 253.94^{b}$ & 147 & $1318.94 \pm 329.07^{a}$ & 188 \\
\hline Magnesium, mg & $255.33 \pm 60.80^{\mathrm{b}}$ & 80 & $307.52 \pm 84.87^{\mathrm{a}}$ & 88 \\
\hline Iron, mg & $9.68 \pm 2.28^{\mathrm{b}}$ & 90 & $11.92 \pm 3.11^{\mathrm{a}}$ & 119 \\
\hline Zinc, mg & $8.63 \pm 1.85^{\mathrm{b}}$ & 108 & $11.34 \pm 3.13^{\mathrm{a}}$ & 103 \\
\hline Copper, mg & $1.06 \pm 0.27^{b}$ & 118 & $1.23 \pm 0.31^{\mathrm{a}}$ & 137 \\
\hline Vitamin A, $\mu \mathrm{g}$ & $836.62 \pm 578.88$ & 120 & $930.91 \pm 557.70$ & 103 \\
\hline Vitamin $\mathrm{D}, \mu \mathrm{g}$ & $2.28 \pm 0.99^{b}$ & 25 & $3.96 \pm 2.95^{\mathrm{a}}$ & 49 \\
\hline Vitamin E, mg & $7.49 \pm 2.61^{b}$ & 94 & $9.40 \pm 3.26^{\mathrm{a}}$ & 94 \\
\hline Thiamin, mg & $0.97 \pm 0.26^{\mathrm{b}}$ & 89 & $1.26 \pm 0.36^{\mathrm{a}}$ & 97 \\
\hline Riboflavin, mg & $1.31 \pm 0.32^{\mathrm{b}}$ & 120 & $1.62 \pm 0.44^{\mathrm{a}}$ & 124 \\
\hline Niacin, mg & $13.20 \pm 4.04^{\mathrm{b}}$ & 94 & $16.22 \pm 4.98^{\mathrm{a}}$ & 101 \\
\hline Vitamin $\mathrm{B}_{6}, \mathrm{mg}$ & $1.55 \pm 0.52^{\mathrm{b}}$ & 105 & $1.92 \pm 0.49^{\mathrm{a}}$ & 120 \\
\hline Folates, $\mu \mathrm{g}$ & $181.02 \pm 54.12^{\mathrm{b}}$ & 45 & $207.27 \pm 57.91^{\mathrm{a}}$ & 52 \\
\hline Vitamin $\mathrm{B}_{12}, \mu \mathrm{g}$ & $3.04 \pm 1.70^{\mathrm{b}}$ & 127 & $4.69 \pm 2.86^{\mathrm{a}}$ & 195 \\
\hline Vitamin C, mg & $56.94 \pm 29.58$ & 70 & $60.30 \pm 32.24$ & 67 \\
\hline
\end{tabular}

${ }^{\mathrm{a}, \mathrm{b}}$ Statistically significant difference between women and men in the examined group at $p<0.05$.

\section{DISCUSSION}

The assessment of the nutritional status of the patients showed that a significant proportion of both the women and men aged 40+ was overweight or obese, which is confirmed by the observations of Polish and foreign researchers (Bronkowska and Sadowska, 2007; Mendis et al., 2011; Ogden et al., 2013; Terlikowska et al., 2012). At the same time, it was observed that a significant proportion of the men and women consumed an insufficient amount of energy from the diet. Probably, the patients deliberately cut down on the amount of food they ate. Similarly, an insufficient dietary energy value was observed by other researchers (Bronkowska and Sadowska, 2007; Garriguet, 2008; Terlikowska et al., 2012). On the basis of WHR, abdominal obesity was diagnosed in over $60 \%$ of the women and $27 \%$ of the men. The fact that the $\mathrm{WC}$ value in the majority of both the women and men exceeded the limits is worrying. The results of this study correspond with the research by Terlikowska et al. (2012). In our study, abdominal obesity was more common among the women than the men. Similar results were obtained by Janghorbani et al. (2007), who stressed that this was particularly evident at an older age. High values of WC and WHR correlate with an increased 
Śmidowicz, A., Reguła, J. (2015). Dietary gender differences in terms of the risk of atherogenesis in Poland. Acta Sci. Pol. Technol. Aliment., 14(3), 257-267. DOI: 10.17306/J.AFS.2015.3.27

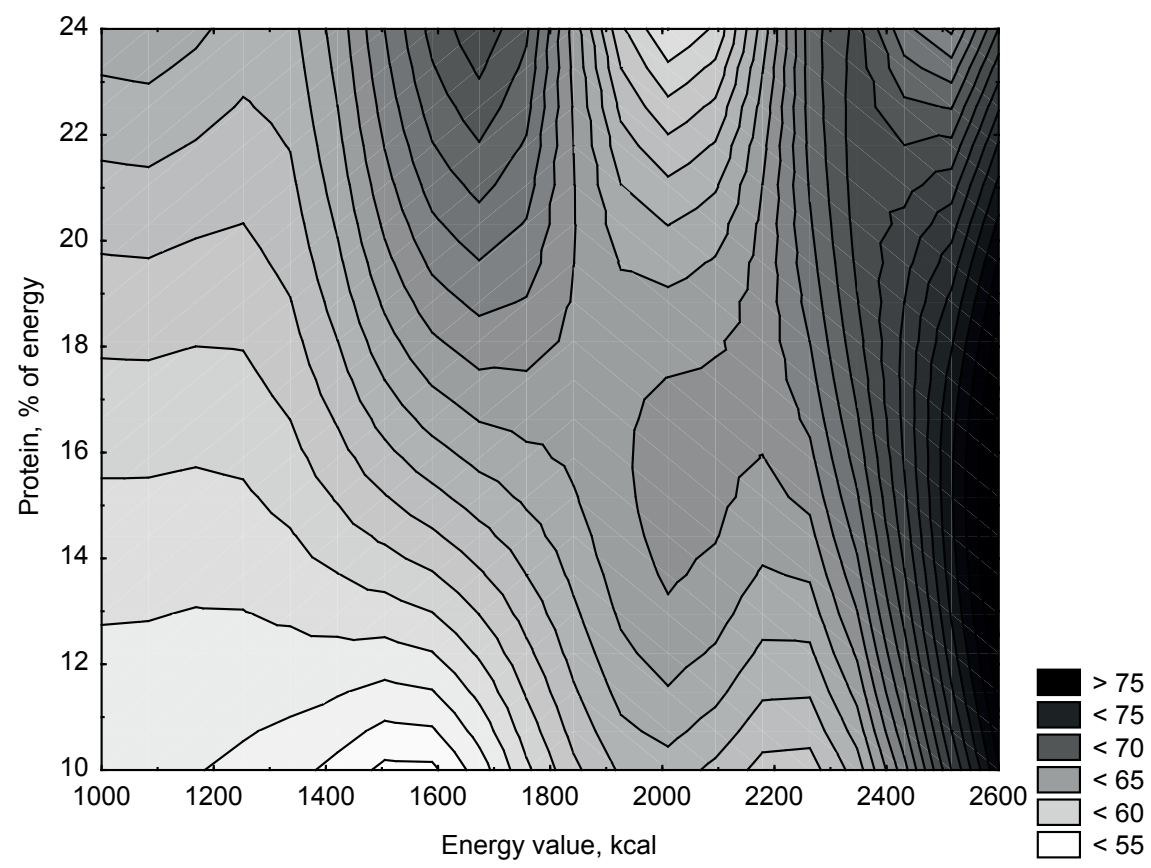

Fig. 1. Contour graph: body weight relative to energy value [kcal] and protein intake [\% of energy], women

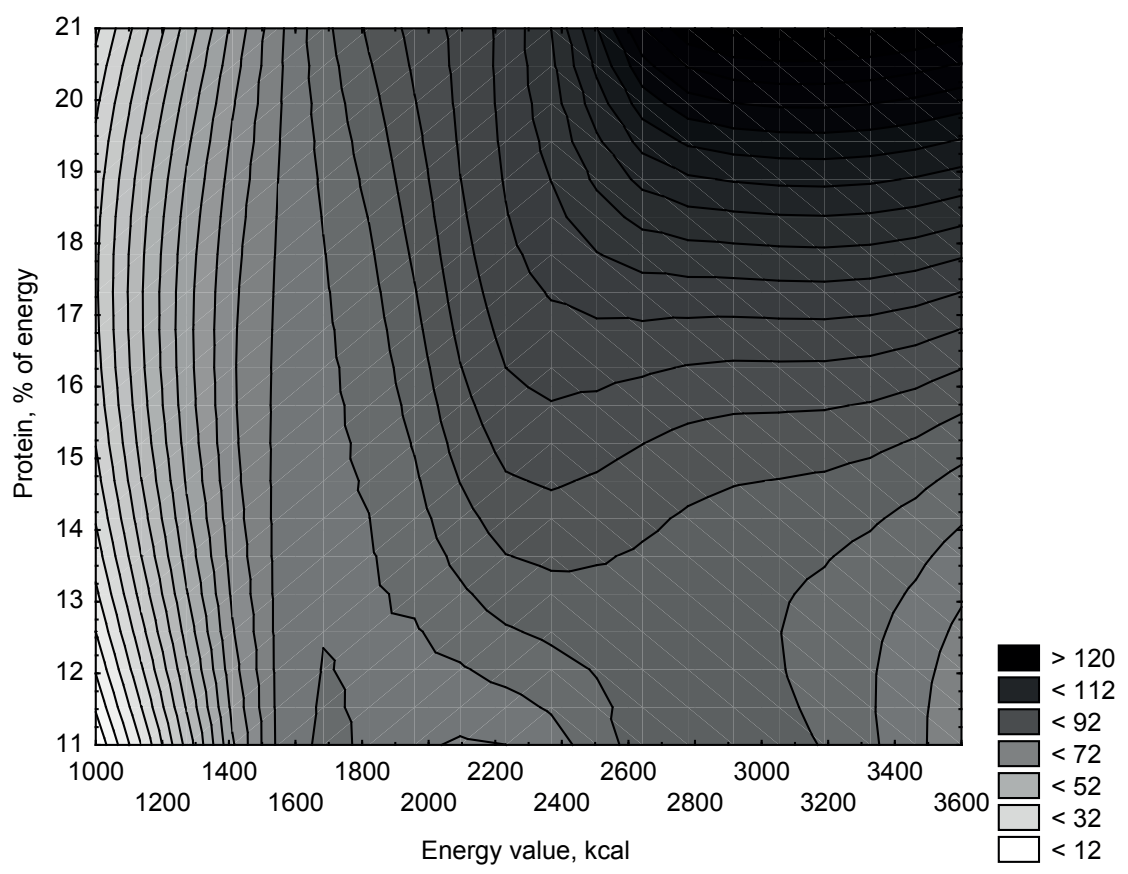

Fig. 2. Contour graph: body weight relative to energy value [kcal] and protein intake [\% of energy], men 
risk of atherosclerosis and CVDs (Klein et al., 2007; Report..., 2003). The analysis of the lipid profile of the patients allowed to identify hypercholesterolemia that was established on the basis of the high values of total cholesterol and the LDL cholesterol fraction. Fortunately, relatively high values of HDL cholesterol, which protects vascular endothelium against the development of atherosclerotic plaques (De Backer et al., 2003), are beneficial. It is not known, however, whether they are high enough in order to significantly reduce the risk of atherogenesis in patients with overweight and obesity, visceral adipose tissue distribution and an unbalanced diet. Although the average ratio of C-LDL/C-HDL was correct, the mean ratio of TC/ $\mathrm{C}-\mathrm{HDL}$ in the men was to high. At the same time, as many as $34 \%$ of the women had elevated levels of the TC/C-HDL ratio. Observational and intervention studies indicate that the risk is lowest when the TC/C-HDL ratio is $<3.5$ (Bersot et al., 2003). Abnormal concentrations of TC occurred with almost equal frequency in the women and men (68\% and 65\%, respectively). In epidemiological studies on the Polish population in the programmes WOBASZ (Pająk et al., 2005) and Pol-MONICA (Podolec et al., 2006) these disorders affected men more frequently. A much higher percentage of people with hypercholesterolemia was observed in the studies of POLKARD-SPOK (Główczyńska et al., 2005) and Maniecka-Bryła et al. (2010). In the surveyed population elevated LDL cholesterol level was more common in the men than women $(67 \%$ and $37 \%$, respectively). In the studies by Maniecka-Bryła et al. (2010) the incidence of these disorders was similar in women and men ( $63 \%$ and $69 \%$, respectively). Values of HDL cholesterol lower than the recommended ones occurred with similar frequency among women and men ( $7 \%$ and $8 \%$, respectively). Similarly results obtained in the studies by Maniecka-Bryła et al. (2010). Much greater prevalence of HDL disorders was obtained in the WOBASZ studies (Pajak et al., 2005). In the studied population a fairly common problem was an increased TG concentration, which concerned almost equally men and women $(22 \%$ and $27 \%$, respectively). The prevalence of TG disorders in the study population was similar to the data for the Polish population (31\% of men, $20 \%$ of women) (Pająk et al., 2005). The problem of lipid disorders is also widely prevalent in European countries and in the world, which is confirmed by numerous studies (AlKaabba et al., 2012; Cai et al., 2012; Scheidt-Nave et al., 2013).

The subjects also struggled with elevated fasting glucose level, which was diagnosed in $22 \%$ of the women and $35 \%$ of the men. According to the WHO (Mendis et al., 2011), impaired fasting glucose is a predisposing factor for future development of diabetes, which is a major risk factor of CVDs.

Besides the adverse nutritional status, diets also contribute to an increased risk of developing the atherosclerotic process. Although the average energy value of DFRs was similar to the accepted standards, the diets were poorly balanced. Most people had a high level of protein and fat intake compared to the production of energy from carbohydrates. It should be noted that the excessive intake of protein, and, in particular, that of animal origin, may be an atherogenic factor due to the high content of both fat and methionine in animal products. Methionine is an amino acid, which leads to increased blood levels of homocysteine, which has an atherogenic effect (Gąsiorowska et al., 2008; Wichlińska-Lipka and Nyka, 2008). Konukoğlu et al. (2003) point out that among obese people even normal levels of homocysteine can damage the endothelium, and lead to oxidative stress and, consequently, the development of atherosclerotic plaque. In our study, we found a positive correlation between the energy from protein and energy in the diet and body weight in the women and men. In addition, among the men protein intake was positively correlated with BMI and WC. The conclusion that protein intake is conducive to obesity is not entirely original. Similar observations were made by Trichopoulou et al. (2002) and McCarty (2000), who hypothesised that protein intake may be the main underlying reason for the increasing occurrence of obesity in the Western world. In our study, a correlation between the level of energy from protein and energy supply and the concentration of C-LDL in the blood of the women was also found. However, one should bear in mind the potential adverse effects of animal protein and favorable ones of vegetable protein on the lipid profile (Kritchevsky, 1995; Reiner et al., 2011; Van Raaij et al., 1981).

What is particularly worrying is the fact that the high levels of fat intake that exceeded $30 \%$ of the energy value of the diet. Given the presence of the multiple 
risk factors for CVDs in the population, these values should be even lower. The high level of SFA consumption is also unfavourable because of raises the level of TC and C-LDL (Reiner et al., 2011; Report..., 2003; Skeaff and Miller, 2009). According to the report of ATP III (National cholesterol..., 2002), substitution of SFA by MUFA may partially compensate for their high supply, but a low intake of PUFA is an additional risk factor for atherosclerosis in the study group.

An important role in the development of atherosclerosis is also played by an increased intake of dietary cholesterol, which increase level of C-LDL (Jarosz, 2012; Reiner et al., 2011). Moreover, persons with hypercholesterolemia are more sensitive to an excess of cholesterol in the diet. It can, therefore, be assumed that in the group of men with known lipid abnormalities, an oversupply of cholesterol will have adverse clinical implications in the form of an even greater increase in C-LDL. Fortunately for the women, only a small percentage of them exceeded the upper limit. The present study revealed a positive correlation between the supply of cholesterol and TG levels in the men's blood, but it requires further investigation.

Attention should be paid to the low intake of dietary fiber. It has been proven that the water soluble fiber reduces the concentration of C-LDL serum, promotes the reduction of the LDL-C/HDL-C ratio, increases excretion of short chain volatile fatty acids that inhibit the activity of hepatic HMGCoA reductase, which causes an increase in the hepatic cholesterol demand required for the synthesis of these acids. Consequently, it reduces the serum concentration of TC and increases the endogenous synthesis. Dietary fiber also reduces postprandial glycemia (Jarosz, 2012; Jenkins et al., 1993; Macintosh and Miller, 2001; Ötles and Ozgoz, 2014; Reiner et al., 2011).

The results of this study indicate a high percentage of people who consume insufficient amounts of antioxidant vitamins, which have the ability to limit the formation of free radicals, lipid peroxides and modification of LDL and lowering TC concentration in the blood (Asplund, 2002; Kłosiewicz-Latoszek et al., 2008; Waśkiewicz and Sygnowska, 2008).

Another problem is an insufficient intake of folate, which next to excessive protein intake may promote the increase in homocysteine concentration in blood plasma and thus increase the risk of CVDs
(Wichlińska-Lipka and Nyka, 2008). The fact that the intake of other triplet's vitamins responsible for the increase concentration of homocysteine, ie. vitamin $B_{6}$ and $\mathrm{B}_{12}$, was sufficient is comforting.

In the present study, there was also an inadequate intake of potassium, calcium and, in women, magnesium, simultaneous with an excessive sodium intake, which may lead to the occurrence of hypertension (Waśkiewicz and Sygnowska, 2008). Vasconen (2003) stresses that mineral nutrients, such as calcium, potassium and magnesium, lower blood pressure, and calcium especially has beneficial effects on serum lipids and may help in weight control, as well.

Similar errors in the diet, unfavourable from the viewpoint of the atherogenesis threat, were also observed by other researchers (Bronkowska and Sadowska, 2007; Terlikowska et al., 2012; Waśkiewicz and Sygnowska, 2008; Waśkiewicz et al., 2005).

\section{CONCLUSIONS}

Our study indicates that inadequate nutrition among the study population both men and women represents a real health danger of developing of atherosclerotic plaque. It should be stressed that there is a need for nutrition education in the age group of $40+$ to modify diet properly.

\section{REFERENCES}

Al-Kaabba, A. F., Al-Hamdan, N. A., Tahir, A. E., Abdalla, A. M., Saeed, A. A., Hamza, M. A. (2012). Prevalence and correlates of dyslipidemia among adults in Saudi Arabia: results from a National Survey. Open J. Endocr. Metab. Dis., 2(4), 89-97.

Asplund, K. (2002). Antioxidant vitamins in the prevention of cardiovascular disease: a systematic review. J. Int. Med., 251(5), 372-392.

Bersot, T. P., Pépin, G. M., Mahley, R. W. (2003). Risk determination of dyslipidemia in populations characterized by low levels of high-density lipoprotein cholesterol. Am. Heart J., 146(6), 1052-1059.

Bronkowska, M., Sadowska, B. (2007). Ocena sposobu żywienia kobiet w okresie okołomenopauzalnym w aspekcie zagrożenia chorobami cywilizacyjnymi - spożycie wybranych składników pokarmowych [Assessing the eating habits of perimenopausal women from the point of view of hazards by the disease of civilization - the 
intake of some selected nutrients]. Żywn. Nauka Techn. Jakość, 6(55), 359-368 [in Polish].

Cai, L., Zhang, L., Liu, A., Li, S., Wang, P. (2012). Prevalence, awareness, treatment, and control of dyslipidemia among adults in Beijing, China. J. Atheroscler. Thromb., 19(2), 159-168.

De Backer, G., Ambrosioni, E., Borch-Johnsen, K., Cifkova, R., Dallongeville, J., Ebrahim, ..., Wood, D. (2003). European Society of Cardiology Committee for Practice Guidelines. European guidelines on cardiovascular disease prevention in clinical practice (constituted by representatives of eight societies and by invited experts). Eur. J. Cardiovasc. Prev. Rehabil., 10(4), S1-10.

Friedewald, W. T., Levy, R. I., Fredrickson, D. S. (1972). Estimation of the concentration of low-density lipoprotein cholesterol in plasma, without use of the preparative ultracentrifuge. Clin. Chem., 18(6), 499-502.

García-Alcalá, H., Genestier-Tamborero, C. N., Hirales-Tamez, O., Salinas-Palma, J., Soto-Vega, E. (2012). Frequency of diabetes, impaired fasting glucose, and glucose intolerance in high-risk groups identified by a FINDRISC survey in Puebla City, Mexico. Diabetes Metab. Syndr. Obes., 5, 403-406.

Garriguet, D. (2008). Under-reporting of energy intake in the Canadian Community Health Survey. Health Report, 19(4), 37-45.

Gąsiorowska, D., Korzeniowska, K., Jabłecka, A. (2008). Homocysteina [Homocysteine]. Farm. Współ., 1, 169175 [in Polish].

Główczyńska, R., Pietrasik, A., Starczewska, M. E., Filipiak, K. J., Opolski, G. (2005). Czynniki ryzyka zdarzeń sercowo-naczyniowych w populacji pacjentów podstawowej opieki zdrowotnej [Risk factors of cardiovascular evens in primary care patients]. Przew. Lek., 6, 52-57 [in Polish].

Janghorbani, M., Amini, M., Willett, W. C., Mehdi Gouya, M., Delavari, A., Alikhani, S., Mahdavi, A. (2007). First nationwide survey of prevalence of overweight, underweight, and abdominal obesity in Iranian adults. Obesity (Silver Spring), 15(11), 2797-2808.

Jarosz, M. (2012). Normy żywienia dla populacji polskiej - nowelizacja [Nutrition standards for the population of Polish - amendment]. Warszawa: IŻŻ [in Polish].

Jarosz, M., Kłosiewicz-Latoszek, L., Charzewska, J., Białkowska, M. (2010) Diagnozowanie zaburzeń stanu odżywiania w praktyce lekarskiej i pielęgniarskiej [Diagnosis of nutritional status disorders in medical practice and care]. Warszawa: IŻŻ [in Polish].
Jenkins, D. J., Wolever, T. M., Rao, A. V., Hegele, R. A., Mitchell, S. J., Ransom, T. P., ..., Würsch, P. (1993). Effect on blood lipids of very high intakes of fiber in diets low in saturated fat and cholesterol. N. Eng. J. Med., 329 (1), 21-26.

Klein, S., Allison, D. B., Heymsfield, S. B., Kelley, D. E., Leibel, R. L., Nonas, C., Kahn, R. (2007). Waist circumference and cardiometabolic risk: a consensus statement from Shaping America's Health: Association for Weight Management and Obesity Prevention; NAASO, The Obesity Society; the American Society for Nutrition; and the American Diabetes Association. Am. J. Clin. Nutr., 85(5), 1197-1202.

Kłosiewicz-Latoszek, L., Szostak, W. B., Podolec, P., Kopeć, G., Pająk, A., Kozek, E., ..., Sieradzki, J. (2008). Polish forum for prevention guidelines on diet. Kardiol. Pol., 66(7), 812-814.

Konukoğlu, D., Serin, O., Ercan, M., Turhan, M. S. (2003). Plasma homocysteine levels in obese and non-obese subjects with or without hypertension; its relationship with oxidative stress and copper. Clin. Biochem., 36(5), 405-408.

Kritchevsky, D. (1995). Dietary protein, cholesterol and atherosclerosis: a review of the early history. J. Nutr., 125 (suppl. 3), 589S-593S.

Macintosh, M., Miller, C. (2001). A diet containing food rich in soluble and insoluble fiber improves glycemic control and reduces hyperlipidemia among patients with type 2 diabetes mellitus. Nutr. Rev., 59(2), 52-55.

Maniecka-Bryła, I., Bryła, M., Maciak, A. (2010). Rozpowszechnienie zaburzeń lipidowych wśród uczestników programu profilaktycznego wczesnego wykrywania chorób układu krążenia w mieście średniej wielkości [Prevalance of lipid metabolism disorders among participants of the programme for early prophylaxis of cardiovascular diseases in a medium-size town]. Med. Ogóln., 16(45), 372-390 [in Polish].

McCarty, M. F. (2000). The origins of western obesity: a role for animal protein? Med. Hypotheses., 54 (3), 488-494.

Mendis, S., Puska, P., Norrving, B. (2011). Global atlas on cardiovascular disease prevention and control. Geneva: World Health Organization.

National cholesterol education program (NCEP) expert panel on detection,evaluation, and treatment of high blood cholesterol in adults (Adult Treatment Panel III). (2002). Third report of the national cholesterol education program (NCEP) expert panel on detection, evaluation, and treatment of high blood cholesterol in adults 
(Adult Treatment Panel III) final report. Circulation, 17, 106(25), 3143-3421.

Ogden, C. L., Carroll, M. D., Kit, B. K., Flegal, K. M. (2013). Prevalence of obesity among adults: United States, 2011-2012. NCHS Data Brief, 131, 1-8.

Ötles, S., Ozgoz, S. (2014). Health effects of dietary fiber. Acta Sci. Pol. Technol. Aliment., 13(2), 191-202.

Pająk, A., Wiercińska, E., Polakowska, M., Kozakiewicz, K., Kaczmarczyk-Chałas, K., Tykarski, A., ..., Zdrojewski, T. (2005). Rozpowszechnienie dyslipidemii u mężczyzn i kobiet w wieku 20-74 lat w Polsce. Wyniki programu WOBASZ [Prevalence of dyslipidemia in men and women between the ages of 20-74 in Poland. Results of the WOBASZ program]. Kardiol. Pol., 63, 6 (supl. 4), S620-S625 [in Polish].

Podolec, P., Karch, I., Pajak, A., Kopeć, G., Broda, G., Drygas, W., ..., Cieśliński, A. (2006). Przegląd polskich badań epidemiologicznych $\mathrm{w}$ kardiologii [Review of epidemiologic studies in cardiology in Poland]. Kardiol. Pol., 64(9), 1031-1037 [in Polish].

Reiner, Z., Catapano, A. L., De Backer, G., Graham, I., Taskinen, M. R., Wiklund, O., ..., Wood, D. (2011). ESC/ EAS Guidelines for the management of dyslipidaemias: The Task Force for the management of dyslipidaemias of the European Society of Cardiology (ESC) and the European Atherosclerosis Society (EAS). Eur. Heart. J., 32(14), 1769-1818.

Report of joint WHO/FAO Expert Consultation (2003). Diet, nutrition and the prevention of chronic diseases. Genewa: WHO Technical Reports Series 916.

Scheidt-Nave, C., Du, Y., Knopf, H., Schienkiewitz, A., Ziese, T., Nowossadeck, E., ..., Busch, M. A. (2013). Prevalence of dyslipidemia among adults in Germany: results of the German Health Interview and Examination Survey for Adults (DEGS1). Bundesgesundheitsbla., 56(5-6), 661-667.

Skeaff, C. M., Miller, J. (2009). Dietary fat and coronary heart disease: summary of evidence from prospective cohort and randomised controlled trials. Ann. Nutr. Metab., 55(1-3), 173-201.
Terlikowska, K. M., Dobrzyńska, B., Witkowska, A., Zujko, M. E. (2012). Sposób żywienia a ryzyko chorób układu sercowo-naczyniowego wśród kobiet w wieku 40-73 lat. Cz. 1. Podstawowe składniki odżywcze, sacharoza, błonnik [The diet and risk of cardiovascular disease in perimenopausal women. Part 1. Basic nutrients, saccharose, fiber]. Bromat. Chem. Toksykol., 45, 3, 669-674 [in Polish].

Trichopoulou, A., Gnardellis, C., Benetou, V., Lagiou, P., Bamia, C., Trichopoulos, D. (2002). Lipid, protein and carbohydrate intake in relation to body mass index. Eur. J. Clin. Nutr., 56(1), 37-43.

Van Raaij, J. M., Katan, M. B., Hautvast, J. G., Hermus, R. J. (1981). Efects of casein versus soy protein diets on serum cholesterol and lipoproteins in young healthy volunteers. Am. J. Clin. Nutr., 34(7), 1261-1271.

Vaskonen, T. (2003). Dietary minerals and modification of cardiovascular risk factors. J. Nutr. Biochem., 14(9), 492-506.

Waśkiewicz, A., Sygnowska, E. (2008). Jakość żywienia dorosłych mieszkańców Polski w aspekcie ryzyka chorób układu krążenia - wyniki badania WOBASZ [The quality of adult Polish population nutrition with recpect to cardiovascular disease - WOBASZ study]. Bromat. Chem. Toksykol., 3(41), 395-398 [in Polish].

Waśkiewicz, A., Sygnowska, E., Jasiński, B., Kozakiewicz, K., Biela, U., Kwaśniewska, M., Głuszek, J., Zdrojewski, T. (2005). Wartość energetyczna i odżywcza diety dorosłych mieszkańców Polski. Wyniki programu WOBASZ [The value of a nutririous and energetic diet for adult inhabitants of Poland. Results of the WOBASZ program]. Kardiol. Pol., 63, 6 (supl. 4), S663-S669 [in Polish].

Wichlińska-Lipka, M., Nyka, W. M. (2008). Rola homocysteiny w patogenezie chorób układu nerwowego [The role of homocysteine in the pathogenesis of diseases of the nervous system]. For. Med. Rodz., 3(2), 223-228 [in Polish]. 


\section{MIĘDZYPtCIOWE RÓŻNICE W SPOSOBIE ŻYWIENIA W ASPEKCIE ZAGROŻENIA ATEROGENEZĄ W POLSCE}

\section{STRESZCZENIE}

Wstęp. Dieta odgrywa istotną rolę w zapobieganiu miażdżycy. Celem badania była ocena różnic w sposobie żywienia oraz stanie odżywienia kobiet i mężczyzn w aspekcie ryzyka miażdżycy.

Materiał i metody. W badaniu wzięło udział 41 kobiet i 49 mężczyzn w wieku 40+. Spożycie składników odżywczych oceniono metodą bieżącego notowania (zapis 7-dniowy). Stan odżywienia określono na podstawie pomiarów antropometrycznych i parametrów biochemicznych krwi. Różnice między składem diety i stanem odżywienia, zależne od płci, oceniono za pomocą jednoczynnikowej analizy wariancji. Zależności pomiędzy stanem odżywienia a czynnikami żywieniowymi stwierdzono za pomocą regresji wielokrotnej.

Wyniki i dyskusja. Znaczna część kobiet i mężczyzn miała nadwagę bądź otyłość, zaburzenia lipidowe i nieprawidłowe stężenie glukozy na czczo. Diety kobiet i mężczyzn były źle zbilansowane. U kobiet stwierdzono istotną korelację między poziomem energii z białka i podażą energii a cholesterolem frakcji LDL. Pozytywną korelację pomiędzy energią z białek i całkowitą podażą energii a masą ciała stwierdzono u kobiet i mężczyzn. Ponadto spożycie białka było skorelowane dodatnio z BMI oraz obwodem talii u mężczyzn. Także u mężczyzn, poziom triacylogliceroli w surowicy korelował ze wzrostem spożycia cholesterolu i zmniejszaniem wartości energetycznej.

Wnioski. Badanie wskazuje, że niewłaściwa dieta zarówno wśród mężczyzn, jak i kobiet jest realnym zagrożeniem zdrowia, powodując rozwój blaszki miażdżycowej.

Słowa kluczowe: zaburzenia lipidowe, stan odżywienia, sposób żywienia, miażdżyca

For citation - Do cytowania

Śmidowicz, A., Reguła, J. (2015). Dietary gender differences in terms of the risk of atherogenesis in Poland. Acta Sci. Pol. Technol. Aliment., 14(3), 257-267. DOI: 10.17306/J.AFS.2015.3.27 